\title{
'Country-of-Origin' effect and online purchase environment: Outlining the need for research
}

\author{
Garima Gupta $^{1, *}$, Abhimanyu Verma ${ }^{2}$ \\ ${ }^{\mathbf{1}}$ Associate Professor, ${ }^{\mathbf{2}}$ Assistant Professor, ${ }^{\mathbf{1}}$ Faculty of Management Studies, University of Delhi, Delhi, ${ }^{2}$ Shaheed Sukhdev College of \\ Business Studies, University of Delhi, Delhi, India \\ *Corresponding Author: Garima Gupta \\ Email: garimagupta77@yahoo.co.in
}

\begin{abstract}
Globalisation has provided organisations with a market platform where brands are available to consumers worldwide, thereby bringing out the importance of country-of-origin into the spotlight. The opening of international marketplace has created a new landscape and placed the country-of origin factor as an appealing area of research. It is a fact that, unlike brand or corporate image, country image, is an influential but uncontrollable element of marketing strategy, especially for the firms that are taking their initial step to go global. For this reason, country-of-origin (COO) and its effect on buyers' purchase behaviour has attracted significant research attention over the past years. The need to understand and examine country-of-origin effect has become all the more pronounced with the shift in focus from offline to online e-commerce. It is in this backdrop that the present review paper seeks to provide a comprehensive understanding of the linkage between country-of-origin effect and consumer decision making, specifically in the context of online purchase environment. In addition to contributing to the existing body of literature, the insights from the present work would provide useful learning to international marketers with respect to the use of country-of-origin information in the age of online purchases.
\end{abstract}

Keywords: Country-of-origin, E-commerce, Consumer decision making, Online purchase environment.

\section{Introduction}

Among the varied areas that have been impacted by Internet technology, purchases facilitated through online purchase platform has radically transformed the shopping environment for consumers as well as businesses. With more than 1 billion users estimated to be online by 2020, the online e-commerce future of India is more intense than ever (The Economist, March 2016). The change has not only established the online presence as a key driver that is used by businesses to stay competitive (Eid and El-Gohary, 2013) but has also witnessed drastic changes in consumers' shopping behaviour in recent years. As posited by Toa et al. (2007), the current era of electronic b-2-b and b-2-c platforms has enabled products, information and reviews to be more easily accessible to the consumers, who use this information in their product evaluation and purchase-related decisions.

Prior studies have shown that providing information about the product's background, such as the country-oforigin and production method, can change the sensory perceptions of product experience, specially with respect of luxury products (GürhanCanli and Maheswaran, 2000; Wansink et al., 2001). Since the country-of-origin is an influential and uncontrollable element of marketing strategy that can be used by marketers to positively enhance sensory perceptions of consumers' offline experience, it becomes equally important to understand and analyze as to how it impacts their product evaluation and decision making in an online purchase environment and hence merits attention of marketers operating in the online era.

\section{Country-of-Origin (COO) and Consumer Decision Making}

The impact of consumers' purchase behaviour due to the country-of-origin has been a widely studied phenomenon. In the process of making rational purchase decisions, consumers use country-of-origin as one of the determinant cues to make quality and performance assessment of the product (Hamin and Eliot, 2006; Olins, 2004). In general terms, researchers have conceptualized country-of-origin as a form of country stereotyping which consumers use when there is an absence of other productspecific information. The country-of-origin effect can thus be related to aspects such as the economic stage or the products/brands produced in the focal country. For instance, studies by Knight and Calantone (1999) and Demirbag et al. (2010) reported that consumers may use the image of people of a particular country as a manifestation of product quality.

As per Parameswaran and Mohan (1994), country-oforigin image is a multi-faceted aspect comprising of three main components- cognitive, affective and conative. While the cognitive component represents consumers' beliefs about the background of a country; the affective component relates to symbolic and emotional value it holds for the consumer. The third component i.e. the conative component deliberates upon capturing consumers' desired interaction with the sourcing country. It can thus be inferred that while the country image serves as the tool for cognitive assessment of product and product quality to consumers, an affective attachment or a favourable image for a particular country provokes the emotional side of consumers. This makes consumers patronise the country with which they can well integrate their sentiments (Pappu et al., 2006).

As an extrinsic cue, $\mathrm{COO}$ play two roles namely, the halo effect and the summary effect, in consumers' 
evaluation of a product or brand (Jaffe and Nebenzahl, 2001). When consumers are not familiar with the products of a country, the country-image and other country-related aspects (such as its stage of economic development, social and cultural systems) serve as stereotypical cues in consumers' evaluation of products choice behaviour (Tse and Gorn, 1993). For instance, depending on their perception of the country, "made in....." label make consumers believe that a product is "superior" or "inferior" (Yasin et al., 2007). In some cases, consumers even refrain themselves from buying products from specific countries due to their past and present grievances. On the other hand, in case of being familiar with a country's products, consumers infer a country's image more easily and directly from its product information. As posited by Han (1989), this subsequently exerts an indirect influence on consumers' brand attitude.

Studies further provide the view that consumers process the country of origin in different ways: while some connect themselves with fond memories of a particular country, others express that a country is known for being excellent at manufacturing a certain product and presents greater quality due to its country-of-origin. It may, in sum, be inferred that information about the country-of-origin has an impact on consumers' preferences, purchase decisions as well as their feelings and emotions.

\section{Research Phases Concerning Country-of-Origin}

Research undertaken in the domain of country-of-origin can be broadly categorised research three phases (Phau and Prendergast, 2000). In the early phase from 1965 to 1973 , the effect of country-of-origin (COO) on buying intentions was examined by Schooler (1965) in the context of Central American market. During this period, Howard and Sheth (1969) too opined that consumers have high probability of using country image as a halo effect in dropping the set of options for the acquisition assessment. In all, this phase focused on understanding the impact of $\mathrm{COO}$ on consumers' brand perception (e.g. Gaedeke, 1973) more than assessing its influence on their buying intentions. More so, studies up till here remained confined to products involving a single country-of-origin and so did not adequately represent the informational environment in which product evaluation takes place. This gap was bridged in the second phase (1982 to 1990 's) wherein researchers started emphasizing on multiple parameters of country-or-origin affecting marketing strategies, such as the relationship of $\mathrm{COO}$ and country of manufacture (e.g. Baughn and Yaprak, 1993). More specifically, the study by Bilkey and Nes (1982) suggested that country-of-origin incorporated with manufacture (or design) serves as a vital aspect of an array of information or cues that determine consumers' purchase intentions. In contrast with the impact of single COO, the study by Peterson and Jolibert (1995) found a different and lesser effect of multiple- parameter $\mathrm{COO}$ on both quality perception and purchase intention.

Further, the rise of streams of country-of-origin (with respect to brand origin, product-country image and country- of-origin for services) guided researchers to push and take it to the next level (Dinnie, 2004) in the third phase of research. Studies categorised products according to four COO sub-parameters: Country-of-Manufacture (COM), Country-of-Parts (COP), Country-of-Assembly (COA) and Country-of-Design (COD) (e.g. Chao, 1993; Insch and McBride, 1998; Ha-Brookshire, 2012; Al-Aali et al., 2015) in their attempt to understand as to how consumers process different pieces of relevant information and the way these attributes interact with each other in consumers' quality evaluations. Results revealed that consumers are not always aware about where a product was assembled or designed and react differently to different parameters (Magnusson et al., 2011). The study by Kien-Quoc (2006) further posited that the importance of these parameters vary across product categories. For example, the importance of Country-ofDesign was found to vary in importance for clothes and personal computers. Adding more to it, not only the developed countries are perceived better in comparison to less developed ones, the differences too are more important with respect to design capabilities than for assembly (Roth and Romeo, 1992).

Highlighting the complexity and multi-dimensionality of the COO construct, Roth and Diamantopoulos (2009) further proposed three different dimensions: Country Image, Product-Country Image and Product Image, that need to be considered in the analysis of the $\mathrm{COO}$ effect on consumers' purchase intentions. While the 'country image' emphasizes on factors such as cognitive beliefs and affective components that contribute to the creation of a country's image, the aspect of 'product-country image' relates the country-image with the products manufactured in a country and takes into account the influence of former on the latter. The third dimension of 'product image' focuses on the quality image associated with products marketed of different countries.

\section{Way Forward: Need for Research in the Context of Online Purchase Environment}

Through a review of existing literature, the present perspective provides an understanding of the role of country-of-origin effect in impacting consumer decisionmaking. A discussion of research phases concerning country-of-origin clearly underlines its influence on consumers' perceptions, evaluation and intentions to purchase. But, this has been examined mostly in respect to consumers' offline decision making. As also asserted by Laroche (2010), online consumer behaviour is a relatively new topic with not adequate research among scholars. The shift of the platform from offline to online mode, however, makes it imperative that decision sequence of consumers, market structures and the characteristics/features of the product in question are understood, analyzed, and resolved in the context of the online purchase environment. The existing literature in this regard mainly concentrates on identifying the factors that affect desire and willingness of consumers to engage in online shopping. Studies, as such, have laid more focus on analyzing consumers' attitudes and 
buying intentions towards Internet purchases (e.g. Jarvenpaa and Todd, 1997; Lowengart and Tractinsky, 2001; Vellido et al., 2000). With only a few number of studies that have acknowledged the salient role of $\mathrm{COO}$ effect as a determinant cue that affects consumers' product evaluations (Reuber and Fischer, 2011) and subsequent purchase intentions (Ching et al., 2013) in an online environment, research incorporating the impact of $\mathrm{COO}$ in the decision sequence adopted for online purchases largely remains in dearth.

The challenging aspect of on-click availability of information of products from different countries give impetus to the companies, marketers and researchers to study country-of-origin effect on consumers' decision making for purchasing of products in an era of e-commerce. Further, an understanding of the impact of country-of-origin becomes all the more relevant when Foreign Direct Investment is being added as a catalyst and as such has led to one of the most voluminous sets of literature within disciplinary subfield of international marketing. In this regard, research concerning the importance and relationship between three sub-components of country of origin (i.e. country image, product country image and product image) will be useful and should be essentially undertaken for the benefit of businesses operating in developing countries like India. In all, the present review calls for the need for future research in this pertinent domain.

\section{References}

1. Ali, A.J., and Al-Aali, A. (2015). Marketing and Ethics: What Islamic ethics have contributed and the challenges ahead. Journal of Business Ethics, 129(4):833-845.

2. Baughn, C.C., and Yaprak A. (1993). Mapping country- oforigin research: recent developments and emerging avenues. In N. Papadopoulos and L.A. Heslop (eds), Product-Country Images, New York: International Business Press, 89-115

3. Chao, P. Partitioning country of origin effects: Consumer evaluations of a hybrid product. Journal of International Business Studies, 1993;24(2):291-306.

4. Chih-Ching, Y., Pei-jou, L., and Chun-Shuo, C. How brand image, country of origin and self-congruity influence internet users' purchase intention. Social Behaviour and Personality: An International Journal, 2013;41(4):599-611.

5. Demirbag, M., Sahadev, S. and Mellahi, K. Country image and consumer preference for emerging economy products: The moderating role of consumer materialism. International Marketing Review, 2010;27(2):41-63.

6. Dinnie, K.J. Country-of-origin 1965-2004: A literature review. Journal of Customer Behaviour, 2004;3(2):165-213.

7. Eid, R. and El-Gohary, H. The impact of E-marketing use on small business enterprises' marketing success. Services Industries Journal, 2013;31(1):31-50.

8. Gaedeke, R. (1973). Consumer attitudes towards products 'Made In' developing countries. Journal of Retailing. 49 (Summer), 13-24.

9. Gerald, H. A cross-national investigation of the effects of country of origin and brand name on the evaluation of a new car. International Marketing Review, 1996;13(5):7697.

29. Reuber, A., and Fischer, E. When nobody knows your name: Country-of-origin as a reputational signal for online businesses. Corporate Reputation Review. 2011;14(1):37-51.
10. Gurhan-Canli, Z., and Maheswaran, D. (2000). Cultural variations in country-of-origin effects. Journal of Marketing Research, 2000;37(3): 309-318.

11. Ha-Brookshire, J., and Yoon, S.H. Country-of-origin factors influencing US consumers' perceived price for multinational products. Journal of Consumer Marketing, 2012;29(6):445454.

12. Hamin, H., and Elliot, G. A less-developed country perspective of consumer ethno-centrism and "Country-of-Origin" effects: Indonesian evidence. Asia-Pacific Journal of Marketing and Logistics. 2006;18(2):79-92.

13. Hamzaoui-Essoussi L., Merunka, D., and Bartikowski, B. Brand origin and country-of-manufacture influences on brand equity and the moderating role of brand typicality. Journal of Business Research. 2011;64(9):973-978.

14. Han, C.M. The role of consumer patriotism in the choice of domestic versus foreign products. Journal of Advertising Research. 1988;28(3):25-32.

15. Howard, J.A. and Sheth, J.N. (1969). The Theory of Buyer Behavior. John Wiley, New York.

16. Insch, G.S., and McBride, J.B. Decomposing the country-oforigin construct: An empirical test of country of design, country of parts and country of assembly. Journal of International Consumer Marketing, 1998;10(4):69-91.

17. Jaffe, E.D., and Nebenzahl, I.D. The effectiveness of sponsored events in promoting a country's image. International Journal of Advertising. 1991;10(3):223-237.

18. Jarvenpaa, S.L., Tractinsky, N., and Vitale, M. Consumer trust in an internet store. Information Technology and Management. 2000;1(1):45-71.

19. Kien-Quoc, V.P. and Simpson, M. The impact of frequency of use on service quality expectations: An empirical study of trans-atlantic airline passengers. The Journal of American Academy of Business, 2006;10(1):1-7.

20. Knight, G.A. and Calantone, R.J. A flexible model of consumer country-of- origin perceptions: A cross- cultural investigation. International Marketing Review. 2000;17(2):127-145.

21. Laroche, M. New developments in modeling internet consumer behaviour: Introduction to the special issue. Journal of Business Research. 2010;63(9):915-918.

22. Lowengart, O., and Tractinsky, N. (2001). Differential effect of product category on shoppers' selection of web-based stores: A probabilistic modelling approach. Journal of Electronic Commerce Research, 2001;2(4):142-156.

23. Olins, W. Branching the nation: The historical context. Journal of Brand Management. 2002;9(4-5):241-248.

24. Pappu, R., Quester, P.G.and Cooksey, R.W. Country image and consumer-based brand equity: Relationships and implications for international marketing. Journal of International Business Studies. 2007;38(5),726.

25. Parameswaran, R., and Mohan, P.R. Facets of country-oforigin image: An empirical assessment. Journal of Advertising, 1994;23(1);43-56.

26. Parameswaran, R. and Yaprak, A. A cross national comparison of consumer research measures. Journal of International Business Studies. 1987;18(1):35-49.

27. Peterson, R.A., and Jolibert, A.P. A meta-analysis of countryof-origin effects. Journal of International Business Studies. 1995;26:883-899.

28. Phau, I., and Prendergast, G. 'Conceptualizing the country of origin of brand. Journal of Marketing Communications, 2000;6(3):159-170.

30. Roth, K.P., and Diamantopoulos, A. Advancing the country image construct. Journal of Business Research. 2009;62(5):726-40. 
31. Roth, M.S. and Romeo, J.B. Matching product and country of image perceptions: A framework for managing country of origin effects. Journal of International Business Studies. 1992;23(3):477-497.

32. Schooler, R.D. (1965). Product bias in the Central American common market. Journal of Marketing Research. 1965;2(4):394-397.

33. The Economist (March 5, 2016). https://www.economist.com/leaders/2016/03/05/india-online

34. Toa, P. L., Liaob, C., and Linc, T. H. Shopping motivations on internet: A study based on utilitarian and hedonic value. Technovation. 2007;27:774-787.

35. Tse, D. K., and Gorn, G. J. An experiment on the salience of country-of-origin in the era of global brands. Journal of International Marketing, 1993;1(1):57-76.
36. Westjohn, S, A. and Magnusson, P. Theory of the Global Consumer. Handbook of Research in International Marketing, 2011;2:317-332.

37. Yasin, N.M., Noor, M.N., and Mohamad, O. (2007). Does images of country of origin matter to brand equity? Journal of Product and Brand Management, 2007;16(1):38-48.

How to cite this article: Gupta G, Verma A. 'Country-of-Origin' effect and online purchase environment: Outlining the need for research. J Manag Res Anal. 2018;5(4):473-476. 